\title{
PARTISIPASI MASYARAKAT DALAM PENGELOLAAN SAMPAH DI KOTA KEDIRI SESUAI DENGAN PERATURAN DAERAH NOMOR 3 TAHUN 2015
}

\author{
*Fendy Artha Prissando ${ }^{1)}$, Tri Ambulanto ${ }^{2)}$ \\ 1) Prodi Administrasi Publik, Fakultas Ilmu Sosial dan Ilmu Politik, Universitas Kadiri, \\ Indonesia \\ 2) Prodi Administrasi Publik, Fakultas Ilmu Sosial dan Ilmu Politik, Universitas Kadiri, \\ Indonesia
}

*Email Korespondensi : arthaprissa@unik-kediri.ac.id

\begin{abstract}
Abstrak
Masyarakat Kota Kediri menyadari pentingnya pengelolaan sampah yang aman dan nyaman bagi lingkungannya sehingga mendorong kesadarannya berpartisipasi terhadap pengelolaan sampah terpadu berbasis masyarakat. Meskipun partisipasi masyarakat cukup baik, akan tetapi tidak bisa dipungkiri dimana masih dijumpai sebagian kecil masyarakat melakukan pembuangan sampah bukan pada tempatnya seperti sungai atau kali dan selokan sehingga dapat menimbulkan banjir dikala musim hujan, juga di pinggir-pinggir jalan sehingga menimbulkan kesan kotor dan mengurangi pemandangan keindahan kota. Tujuan dari penelitian ini adalah untuk mendeskripsikan partisipasi masyarakat Kota Kediri dalam pengelolaan sampah berdasarkan Peraturan Daerah Nomor 3 Tahun 2015. Penelitian ini menggunakan metode penelitian deskriptif kualitatif. Sedangkan teknik pemilihan informan menggunakan purposive sampling dan snowball sampling. Guna melakukan keabsahan data, peneliti melakukan triangulasi. Teknik analisa data yang digunakan dalam penelitian ini dengan menggunakan analisis kualitatif. Adapun langkahlangkahnya menurut Moleong (2010:189-192) meliputi reduksi data penafsiran dengan penyimpulan data dari lapangan dan diaplikasikan dilanjutkan dengan membuat suatu rangkuman data. Rangkuman data tersebut selanjutnya ditafsirkan sesuai dengan metode analisis. Hasil dari penelitian ditemukan bahwa kurangnya kesadaran sebagian masyarakat, dan tidak semua masyarakat mengetahui teknik pemilahan sampah antara organik dan non-organik.
\end{abstract}

Kata Kunci: Partisipasi Masyarakat; Pengelolaan Sampah; Peraturan Daerah

\begin{abstract}
The people of Kediri City realize the importance of safe and comfortable waste management for their environment so that they encourage their awareness to participate in community-based integrated waste management. Even though community participation is quite good, it is undeniable that a small number of people still dispose of garbage in places such as rivers or
\end{abstract}


streams and ditches so that it can cause flooding during the rainy season, also on the sides of the road so that it creates a dirty impression and reduces the view. the beauty of the city. The purpose of this study was to describe the participation of the people of Kediri City in waste management based on Regional Regulation Number 3 of 2015. This study used a qualitative descriptive research method. Meanwhile, the informant selection technique used purposive sampling and snowball sampling. To validate the data, the researcher conducted triangulation. The data analysis technique used in this research is qualitative analysis. The steps according to Moleong (2010: 189-192) include reduction of interpretive data by summarizing data from the field and applying it followed by making a summary of the data. The data summary is then interpreted according to the method of analysis. The results of the study found that the lack of awareness of some people, and not all people know the technique of sorting waste between organic and nonorganic.

Keywords: Society participation; Waste management; Local regulation

\section{PENDAHULUAN}

Sampah merupakan salah satu permasalahan yang dihadapi oleh banyak kota di seluruh dunia. Semakin tingginya jumlah penduduk dan aktivitasnya, membuat volume sampah terus meningkat. Akibatnya, untuk mengatasi sampah diperlukan biaya yang tidak sedikit dan lahan yang semakin luas. Disamping itu, tentu saja sampah membahayakan kesehatan dan lingkungan jika tidak dikelola dengan baik.

Permasalahan sampah di perkotaan pada saat ini seolah-olah telah menjadi momok bagi para pengelola kota. Penumpukan sampah di sudut-sudut kota karena tidak terangkut dan karena Tempat Pembuangan akhirnya dimasalahkan oleh masyakat telah menjadi isyu di hampir semua kota-kota besar di Indonesia. Penumpukan sampah selain berimplikasi pada estetika, pada tingkatan tertentu akan mengakibatkan terjadinya penyebaran penyakit, khususnya bagi penyakit-penyakit yang disebarkan oleh binatang, baik serangga yaitu lalat dan nyamuk maupun oleh rodentia seperti tikus.

Tidak terkelolanya sampah dengan semakin menjadi-jadi setelah era otonomi daerah. Dimana daerah Kota yang hampir seluruh pengelolaan sampahnya dikelola secara komunal oleh suatu intansi pemerintah yaitu Dinas Kebersihan dan Lingkungan Hidup atau PD Kebersihan, tidak bisa dengan mudah mendapatkan lahan untuk tempat pembuangan akhir yang biasanya berada di daerah pinggiran yang secara administratif tidak termasuk ke dalam daerahnya. Hal ini akan semakin memburuk mengingat perkembangan penduduk kota yang terus meningkat dari tahun ke tahun. 
Pada tahun 1980 persentase jumlah penduduk kota di Indonesia adalah 27,29\% dari Jumlah penduduk Indonesia, sementara pada tahun 1990 persentase tersebut bertambah menjadi 30,93\%. Diperkirakan pada tahun 2020 persentase jumlah penduduk kota di Indonesia mencapai 50\% dari jumlah penduduk Indonesia. Sejalan dengan itu, maka peningkatan jumlah sampah yang dihasilkan di Indonesia diperkirakan akan bertambah 5 kali lipat pada tahun 2020. Rata-rata produksi sampah tersebut diperkirakan akan meningkat dari 800 gram per hari per kapita pada tahun 1995 menjadi 910 gram per hari per kapita pada tahun 2003.

Untuk kota Jakarta misalnya, pada tahun 1998/1999 produksi sampah per hari mencapai 26.320 meter kubik. Dibandingkan tahun 1996/1997, produksi sampah di Jakarta tersebut naik sekitar $18 \%$. Hal ini diakibatkan bukan saja karena pertumbuhan penduduk tetapi juga karena meningkatnya timbulan sampah per kapita yang disebabkan oleh perbaikan tingkat ekonomi dan kesejahteraan. Hingga saat ini, penanganan dan pengelolaan sampah tersebut masih belum optimal. Baru 11,25\% sampah di daerah perkotaan yang diangkut oleh petugas, 63,35\% sampah ditimbun/dibakar, 6,35\% sampah dibuat kompos, dan 19,05\% sampah dibuang ke kali/sembarangan. Sementara untuk di daerah pedesaan, sebanyak 19\% sampah diangkut oleh petugas, 54\% sampah ditimbun/dibakar, 7\% sampah dibuat kompos, dan 20\% dibuang ke kali/sembarangan (BPS 2021).

Dengan kondisi semacam itu maka diperlukan suatu terobosan-terobosan dalam pengelolaan sampah. Masyarakat perlu dilibatkan dalam upaya ini agar bisa didapatkan cara penanganan yang paling tepat. Tanpa penanganan yang tepat, sampah akan mengakibatkan terjadinya degradasi kualitas lingkungan hidup manusia. Oleh karena itu, sangat perlu diterapkan konsep pengelolaan sampah yang berkelanjutan (sustainable waste management) sebagai turunan dari konsep pembangunan berkelanjutan berwawasan lingkungan. Pengelolaan sampah yang berkelanjutan diartikan sebagai suatu upaya menggunakan sumberdaya materi secara efisien untuk mengurangi jumlah sampah yang dihasilkan. Penanganan pada sumber sampah dihasilkan harus menggunakan penanganan yang secara aktif mengkontribusi pada bidang ekonomi, sosial dan tujuantujuan lingkungan pembangunan berkelanjutan. 
Pengelolan sampah berkelanjutan, sebagaimana juga isu-isu lingkungan yang lain, dalam pelaksanaannya memerlukan partisipasi masyarakat (Sulistiyorini et al., 2015). Dalam Deklarasi Rio yang dihasilkan dalam Konferensi Tingkat Tinggi (KTT) Bumi tahun 1992, dinyatakan bahwa pemerintah mengatasi masalah isu lingkungan hidup bersama dengan partisipasi masyarakat. Pemerintah diwajibkan memfasilitasi dan mendorong kesadaran dan partisipasi masyarakat dengan menyediakan informasi yang luas dan dapat dicapai (Nugraha et al., n.d.).

Pengelolaan sampah dimaksudkan agar sampah tidak membahayakan kesehatan manusia dan tidak mencemari lingkungan. Pengelolaan sampah juga dilakukan untuk memperoleh manfaat atau keuntungan bagi manusia. Hal ini didasari oleh pandangan bahwa sampah adalah sumber daya yang masih bisa dimanfaatkan dan bahkan memiliki nilai ekonomi. Pandangan tersebut muncul seiring dengan semakin langkanya sumber daya alam dan semakin rusaknya lingkungan. Sampah merupakan konsekuensi dari semua aktifitas yang dilakukan manusia. Apabila tidak terdapat kemampuan masyarakat dalam pengelolaan sampah, sampah dapat menimbulkan permasalahan lingkungan (Anjaswara et al., 2020).

Masalah pengelolaan sampah juga terjadi di Kota Kediri. Timbunan sampah yang selalu bertambah tiap tahunnya, menyebabkan banyak permasalahan terjadi di Tempat Pembuangan Akhir (TPA) (Anggraini, 2015). Pengolahan sampah sudah dilakukan pemerintah setempat sejak tahun 2008. Usaha tersebut dengan membangun unit komposter dengan partisipasi masyarakat. Namun pada aplikasinya masyarakat tidak terlibat secara langsung karena mereka beranggapan pengelolaan persampahan ini adalah tanggung jawab pemerintah. Penelitian ini bertujuan untuk mengidentifikasi kinerja operasional pengelolaan sampah pada unit komposter di Kota Kediri dengan menggunakan analisa kinerja unit komposter baik oprasional ataupun non-operasional, analisis tingkat partisipasi masyarakat dan analisis Multi Dimensional Scaling (MDS). Berdasarkan hasil analisis Multi Dimensional Scaling (MDS) menghasilkan jenis pengolahan sampah yaitu komposting dan daur ulang kertas. Setelah proses analisis menghasilkan arahan pengelolaan sampah terpadu berbasis masyarakat Kota Kediri sesuai 
dengan jenis pengolahan sampah yang dipilih masyarakat yaitu komposing dan daur ulang kertas (Saputri, 2015).

Sistem pengelolaan persampahan terutama untuk daerah perkotaan, harus dilaksanakan secara tepat dan sistemastis. Kegiatan pengelolaan persampahan akan melibatkan penggunaan dan pemanfaatan berbagai prasarana dan sarana persampahan yang meliputi pewadahan, pengumpulan, pemindahan, pengangkutan, pengolahan maupun pembuangan akhir. Masalah sampah berkaitan erat dengan dengan pola hidup serta budaya masyarakat itu sendiri. Oleh karena itu penanggulangan sampah bukan hanya urusan pemerintah semata akan tetapi penanganannya membutuhkan partisipasi masyarakat secara luas.

Jumlah sampah ini setiap tahun terus meningkat sejalan dan seiring meningkatnya jumlah penduduk dan kualitas kehidupan masyarakat atau manusianya dan disertai juga kemajuan ilmu pengetahuan teknologi yang menghasilkan pula pergeseran pola hidup masyarakat yang cenderung konsumtif. Timbunan sampah tersebut dapat menjadi tempat perkembangan penyakit dan menurunkan kualitas lingkungan serta menimbulkan gangguan estetika bila tidak ditangani dengan baik.

\section{TINJAUAN PUSTAKA}

Pasal 30 mengatur tentang peran masyarakat. Masyarakat dapat berperan dalam pengelolaan sampah yang diselenggarakan oleh Pemerintah Daerah. Bentuk peran serta masyarakat dalam pengelolaan sampah sebagaimana meliputi:

a. Menjaga kebersihan lingkungan,

b. Aktif dalam kegiatan pengurangan, pengumpulan, pemilahan, pengangkutan, dan pengolahan sampah; dan

c. Pemberian saran, usul, pengaduan, pertimbangan, dan pendapat kepada Pemerintah Daerah dalam upaya peningkatan pengelolaan sampah di wilayahnya. melakukan usaha-usaha untuk meningkatkan peran masyarakat dalam pengelolaan sampah.

Peningkatan peran masyarakat sebagaimana dimaksud dalam Pasal 30 dilaksanakan dengan cara: 

a. Sosialisasi.
b. Mobilisasi.
c. Kegiatan gotong royong. dan/atau
d. Pemberian insentif.

Peningkatan peran masyarakat sebagaimana tersebut diatas dilaksanakan dengan cara:
a. Mengembangkan informasi peluang usaha di bidang persampahan, dan/atau
b. Pemberian insentif.

Peningkatan peran masyarakat sebagaimana tersebut diatas dilaksanakan dengan cara:
a. Penyediaan media komunikasi,
b. Aktif dan secara cepat memberi tanggapan, dan/atau
c. Melakukan jaringan pendapat aspirasi masyarakat.

\section{METODE PENELITIAN}

Penelitian ini menggunakan metode penelitian deskriptif kualitatif. Djam'an Satori (2011: 23) mengungkapkan bahwa penelitian kualitatif dilakukan karena peneliti ingin mengeksplor fenomena-fenomena yang tidak dapat dikuantifikasikan yang bersifat deskriptif seperti proses suatu langkah kerja, formula suatu resep, pengertian-pengertian tentang suatu konsep yang beragam, karakteristik suatu barang dan jasa, gambar-gambar, gaya-gaya, tata cara suatu budaya, model fisik suatu artifak dan lain sebagainya.

Selain itu, Sugiono (2012:9) juga mengemukakan penelitian kualitatif sebagai metode penelitian yang berlandaskan pada filsafat postpositivisme, digunakan untuk meneliti pada kondisi objek alamiah, dimana peneliti adalah sebagai instrumen kunci, teknik pengumpulan data dengan triangulasi, analisis data bersifat induktif atau kualitatif, dan hasil penelitian kualitatif lebih menekankan makna daripada generalisasi.

Dalam Penelitian ini lokasi penelitiannya adalah Kota Kediri dan untuk menguatkan penelitian, peneliti juga menggali data dan informasi tambahan dari Dinas Lingkungan Hidup, Kebersihan dan Pertamanan (DLHKP) Kota Kediri. Sumber data primer 
diperoleh hasil observasi partisipatif pasif dan dialog atau wawancara dengan Kepala Dinas, Staf dan pegawai serta masyarakat sesuai dengan kapasitas dan kompetensinya. Sedangkan teknik pemilihan informan menggunakan purposive sampling dan snowball sampling. Guna melakukan keabsahan data, peneliti melakukan triangulasi. Trianggulasi adalah cara yang paling umum digunakan dalam penjaminan validitas data dalam penelitian kualitatif. Trianggulasi merupakan teknik peme-riksaan keabsahan data dengan memanfaatkan sesuatu yang lain diluar data itu untuk keperluan pengecekan data atau sebagai pembanding terhadap data itu. Teknik analisa data yang digunakan dalam penelitian ini dengan menggunakan analisis kualitatif. Adapun langkah-langkahnya menurut Moleong (2010:189-192) meliputi reduksi data penafsiran dengan penyimpulan data dari lapangan dan diaplikasikan dilanjutkan dengan membuat suatu rangkuman data. Rangkuman data tersebut selanjutnya ditafsirkan sesuai dengan metode analisis. Dalam penafsiran data dilakukan secara komprensif berdasarkan teori-teori yang mendukung yang pada akhirnya ditarik suatu kesimpulan.

\section{HASIL DAN PEMBAHASAN}

Pengelolaan sampah di Kota Kediri regulasi yang dipergunakan adalah Perda Nomor 3 Tahun 2015 Tentang Pengelolaan Sampah. Bab II Ruang Lingkup, Asas dan Tujuan, Pasal 2 dengan tegas menyebutkan:

1. Ruang lingkup pengelolaan sampah dalam Peraturan Daerah ini, terdiri atas:

a. sampah rumah tangga; dan

b. sampah sejenis sampah rumah tangga.

2. Sampah rumah tangga sebagaimana dimaksud pada ayat (1) huruf a berasal dari kegiatan sehari-hari dalam rumah tangga, tidak termasuk tinja dan sampah spesifik.

3. Sampah sejenis sampah rumah tangga sebagaimana dimaksud pada ayat (1) huruf b berasal dari kawasan komersial, kawasan industri, kawasan khusus, fasilitas sosial, fasilitas umum, dan/atau fasilitas lainnya.

Selanjutnya Pasal 3 menegaskan: Pengelolaan sampah diselenggarakan berdasar asas tanggung jawab, asas berkelanjutan, asas manfaat, asas keadilan, asas kesadaran, asas 
kebersamaan, asas keselamatan, asas keamanan dan asas nilai ekonomi. Juga Pasal 4, Pengelolaan sampah bertujuan untuk meningkatkan kesehatan masyarakat dan kualitas lingkungan serta menjadikan sampah sebagai sumber daya.

Selain apa yang telah dijelaskan diatas, juga diatur pada Bab V tentang Pengelolaan Sampah, pada Bagain Kesatu: Umum, Pasal 10 disebutkan Pengelolaan sampah terdiri atas:
a. pengurangan sampah; dan
b. penanganan sampah.

Bagian Kedua: Perencanaan, Pasal 11 menyebutkan:

1. Pemerintah Daerah menyusun rencana pengurangan dan penanganan sampah yang dituangkan dalam rencana strategis dan rencana kerja tahunan.

2. Rencana pengurangan dan penanganan sampah sebagaimana dimaksud pada ayat (1) sekurang-kurangnya memuat:

a. target pengurangan sampah;

b. target penyediaan sarana dan prasarana pengurangan dan penanganan sampah mulai dari sumber sampah sampai dengan TPA;

c. pola pengembangan kerjasama antar pemerintah daerah, kemitraan antara pemerintah daerah dengan badan usaha dan partisipasi masyarakat;

d. kebutuhan penyediaan pembiayaan yang ditanggung oleh pemerintah daerah dan masyarakat; dan

e. rencana pengembangan dan pemanfaatan teknologi yang ramah lingkungan dalam memenuhi kebutuhan mengguna ulang, mendaur ulang, dan penanganan akhir sampah.

Dan pada Bagian Ketiga: Pelaksanaan, disebutkan pada Pasal 12:

1. Pengurangan sampah dilakukan dengan cara:
a. pembatasan timbulan sampah;
b. pendauran ulang sampah; dan/atau
c. pemanfaatan kembali sampah.

2. Pengurangan sampah sebagaimana dimaksud pada ayat (1) dilakukan melalui kegiatan: 
a. pemantauan dan supervisi pelaksanaan rencana pemanfaatan bahan produksi ramah lingkungan oleh pelaku usaha; dan

b. fasilitasi kepada masyarakat dan dunia usaha dalam mengembangkan dan memanfaatkan hasil daur ulang, pemasaran hasil produk daur ulang, dan guna ulang sampah.

Selanjutnya Pasal 13, Penanganan sampah dilakukan dengan cara:

a. pemilahan;

b. pengumpulan;

c. pengangkutan;

d. pengolahan; dan

e. pemrosesan akhir sampah.

Bab dan pasal inilah salah satu regulasi yang dipergunakan oleh Dinas Lingkungan Hidup, Kebersihan dan Pertamanan (DLHKP) Kota Kediri dalam menangani dan mengelola sampah yang ada di Kota Kediri.

Berdasarkan hasil penelitian dapat dijelaskan bahwa institusi yang bertanggung jawab dalam pengelolaan sampah di Kota Kediri adalah Dinas Lingkungan Hidup, Kebersihan dan Pertamanan (DLHKP). Kelembagaan ini diatur dalam Perwali Kota Kediri Nomor 51 Tahun 2016 Tentang Kedudukan, Susunan Organisasi, Tugas dan Fungsi serta Tata Kerja Dinas Lingkungan Hidup, Kebersihan dan Pertamanan.

Dalam implementasi struktural organisatoris ditangani langsung oleh bagian yang berkompeten terhadap masalah persampahan yaitu Bidang Kebersihan dan Pengelolaan Sampah yang dibantu oleh 3 Seksi yaitu Seksi Penanganan Sampah, Seksi Pelayanan Kebersihan, dan Seksi Pemanfaatan Sampah dan Penanganan Limbah B3. Masingmasing mempunyai tugas pokok dan fungsi aga semua dapat bekerja secara efektif, efisien, tepat guna, dan tepat sasaran dalam upaya memberikan pelayanan kepada masyarakat Kota Kediri.

Disamping tanggung jawab kelembagaan pada Organisasi Perangkat Daerah (OPD) dalam operasionalnya juga melibatkan peran swasta maupun masyarakat mulai dari tingkat RT, RW, Kelurahan, Kecamatan, dan lembaga-lembaga yang interest terhadap sampah seperti Bank Sampah. Bank Sampah yang sudah tersebar di 3 
Kecamatan, Sekolah, dan Pasar. Untuk Kecamatan Kota sebanyak 30 Bank Sampah, Kecamatan Pesantren sebanyak 17 Bank Sampah, Kecamatan Mojoroto sebanyak 28 Bank Sampah, Komunitas Sekolah sebanyak 15 Bank Sampah, dan Pasar sebanyak 3 Bank Sampah. Bila ditotal di Kota Kediri terdapat 93 Bank Sampah dengan 230 Kader Bank Sampah dan mereka diberi honorarium dari Pemerintah Kota Kediri.

Jumlah tenaga yang dimiiki oleh DLHKP Kota Kediri yang menangani sampah di tingkat TPS dan TPA ada sebanyak 38 orang, sedangkan untuk pasukan kuning ada 195 orang sehingga total ada 233 orang. Sedangkan untuk menangani sampah warga di tiaptiap rumah tangga, masyarakat berswadaya dengan memperkerjakan orang dan diberi upah untuk mengambil sampah yang kemudian dibawa ke TPS. Kapasitas ketenagaan yang bertanggung jawab dalam pengelolan sampah lebih dikonsentrasikan pada titik-titik TPS dan pengangkutan ke TPA Lebak Tumpang kawasan Gunung Klotok Kelurahan Pojok Kecamatan Mojoroto.

Sehubungan dengan keterbatasan jumlah tenaga yang ada, maka petugas kebersihan akan melakukan pengambilan sampah rumah tangga secara terjadwal. Hal ini untuk meminimalisir volume sampah di tempat pembuang akhir (TPA) yang mulai tidak terkendali. Karena itu DLHKP Kota Kediri selalu mengkampanyekan pemilihan sampah, dimana sampah rumah tangga dipilah menjadi dua jenis, yakni organik dan non organik. Upaya ini untuk meminimalkan produksi sampah sejak di tingkat rumah tangga.

DLHKP Kota Kediri dalam melaksanakan tugas dan fungsi dalam pengelolaan sampah di Kota Kediri didukung oleh sarana dan prasarana yang cukup memadai berupa arm roll dan kendaraan truk yang mengangkut sampah dari TPS menuju Ke TPA, dan mesin eskavator untuk meratakan tumpukan sampah agar tidak menggunung dan membahayakan warga terutama para pemulung yang ada di tempat itu.

Disamping itu juga ada Motor Tossa untuk mengangkut sampah warga maupun sampah-sampah yang ada di pinggir-pinggir jalan, serta gerobak sampah yang didistribusikan pada RT dan RW. Tempat pengolahan sampah menjadi kompos juga disediakan agar sampah-sampah itu masih ada manfaatnya untuk digunakan menjadi penyubur tanaman. 
Sarana dan prasarana tersebut diatas dipergunakan menangani pengelolaan sampah dari hulu sampai hilir yang dimiliki oleh DLHKP Kota Kediri, meskipun ada beberapa yang perlu mendapatkan penggantian misalnya arm roll dan truk serta gerobak sampah dorong. Dihadapkan pada kondisi seperti itu, pengelolaan sampah harus tetap berjalan sesuai dengan jadwal yang telah ditentukan agar tidak terjadi penumpukan sampah sehingga mengakibatkan lingkungan menjadi kotor dan bau serta berpengaruh terhadap kesehatan masyarakat.

Mengingat akan pentingnya sarana dan prasarana yang kadangkala mengalami gangguan, maka masyarakat terus diedukasi untuk mengurangi produk sampah melalui cara biopori atau memisahkan sampah organik dan non organik agar dapat didaur ulang sehingga mempunyai daya guna dan nilai guna bagi masyarakat itu sendiri.

Partisipasi Masyarakat merupakan suatu keterlibatan masyarakat baik personal individual maupun kelompok untuk menangani masalah persampahan agar semua ikut bertanggungjawab di dalamnya. Sampah adalah produk rumah tangga yang tidak dapat dihindari dan terjadinya setiap saat dan setiap hari. Karena ini sudah menjadi bagian dari rumah tangga, maka masyarakat Kota Kediri menyadari pentingnya pengelolaan sampah yang aman dan nyaman bagi lingkungannya sehingga mendorong kesadarannya berpartisipasi terhadap pengelolaan sampah terpadu berbasis masyarakat.

Meskipun partisipasi masyarakat cukup baik, akan tetapi tidak bisa dipungkiri dimana masih dijumpai sebagian kecil masyarakat melakukan pembuangan sampah bukan pada tempatnya seperti sungai atau kali dan selokan sehingga dapat menimbulkan banjir dikala musim hujan, juga di pinggir-pinggir jalan sehingga menimbulkan keesan kotor dan mengurangi pemandangan keindahan kota. Salah satu bukti partisipasi itu adalah menyiapkan petugas pemungut sampah di tiap RW atau lingkungan untuk dibawa ke TPS terdekat yang disiapkan oleh DLHKP Kota Kediri. Disamping itu hampir di setiap kelurahan yang ada di wilayah kecamatan, sekolah dan pasar sudah ada Bank Sampah yang menampung sampah-sampah yang dapat dijual atau di daur ulang sehingga dapat mengurangi produk sampah warga sekaligus memperoleh hasil yang dapat digunakan untuk menambah kebutuhan rumah tangganya. Upaya ini juga sebagai refleksi dari 
kebijakan DLHKP Kota Kediri pada tahun 2021 untuk menekan atau mengurangi sampah hingga $18 \%$, dan saat ini baru tercapai sekitar $7 \%$.

Berdasarkan hasil perhitungan dalam analisis multidimensional scaling (MDS), diperoleh jenis pengolahan sampah yang sesuai untuk diterapkan di Kota Kediri salah satunya adalah pembuatan kompos (komposting) dan daur ulang kertas, sebagai strategi pemberdayaan masyarakat. Arahan pemberdayaan masyarakat dalam pengelolaan sampah menitik beratkan pada konsep pembangunan yang partisipatif. Melalui konsep inilah partisipasi masyarakat dapat terbangun dengan baik.

Pengelolaan sampah di Kota Kediri dengan berbagai dimensi dan implemenasinya, ternyata masih dijumpai pula beberapa faktor yang menjadi penghambatnya antara lain:

1. Pengangkutan sampah di Kota Kediri terkendala oleh sarana dan prasarana seperti terbatasnya jumlah kendaraan pengangkut khususnya arm roll dan dump truck. Saat ini DLHKP hanya mempunyai 27 alat angkut sampah berupa truk arm roll dan tidak mempunyai dump truck. Jumlah itu jauh dari kebutuhan ideal yang mencapai 30 kendaraan angkut sampah. Sebagian arm roll yang dimiliki ada yang sudah berusia tua. Terakhir pengadaan kendaraan dilakukan pada tahun 2018 lalu.

2. Kurangnya kesadaran sebagian masyarakat untuk tidak membuang sampah di sungai, kali, selokan, dan pinggir jalan Meskipun sudah diberi peringatan baik tertulis maupun tidak tertulis, namun masih ada saja yang tidak mengindahkannya dan tetap membuang sampah di tempat-tempat tersebut. Kebiasaan masyarakat seperti ini membuat keadaan lingkungan kurang sehat, membuat sungai menjadi tercemar dan air sungai menjadi tidak jernih dan menimbulkan bau tidak sedap. Pengangkatan sampah yang ada di sungai belum berjalan secara maksimal, dikarenakan sarana dan prasarana yang belum memadai.

3. Tidak semua masyarakat mengetahui teknik pemilahan sampah antara organik dan non-organik. Sampah organik dan non-organik harus dipisah karena proses pengolahannya yang berbeda. Jika masyarakat melakukan hal ini, maka sampah yang ada akan lebih bermanfaat. Namun sayangnya masyarakat lebih memilih membuang sampah begitu saja. Kumpulan sampah organik seperti daun gugur, sampah sisa 
pertanian, dan sampah dari sayuran dapur bisa diolah sendiri oleh masyarakat untuk dijadikan pupuk kompos. Sementara itu sampah non-organik seperti plastik, kaleng, karet dapat didaur ulang menjadi barang baru yang bernilai ekonomis.

Berdasarkan uraian dan penjelasan sebagaimana tersebut dengan runtut dan detail serta faktual, maka dapat disimpulkan bahwa implementasi pengelolaan sampah di Kota Kediri berpijak pada ketentuan peraturan perundangan yang berlaku yaitu Peraturan Daerah Kota Kediri Nomor 3 Tahun 2015 Tentang Pengelolaan Sampah, dan dilaksanakan dengan baik. Implementasi tersebut mempergunakan parameter tentang regulasi, kelembagaan, ketenagaan, sarana prasarana, dan partisipasi masyarakat. Kelima asumsi yang dijadikan indikator telah terbukti dan dipergunakan baik secara parsial maupun holistik integralistik yang saling berinteraksi antara satu dengan yang lainnya. Ternyata dalam implementasinya masih dijumpai pula beberapa faktor yang menjadi penghambatnya seperti: kendala sarana dan prasarana terutama terbatasnya jumlah kendaraan pengangkut yaitu arm roll dan truck, kurangnya kesadaran sebagian masyarakat, dan tidak semua masyarakat mengetahui teknik pemilahan sampah antara organik dan non-organik.

\section{KESIMPULAN DAN SARAN}

Dalam pelaksanaannya masih dijumpai pula beberapa faktor yang menjadi penghambatnya seperti: 1) kendala sarana dan prasarana terutama terbatasnya jumlah kendaraan pengangkut yaitu arm roll dan dump truck, 2) kurangnya kesadaran sebagian masyarakat, dan 3) tidak semua masyarakat mengetahui teknik pemilahan sampah antara organik dan non-organik. Dari beberapa faktor yang menjadi penghambatnya, terutama kurangnya kesadaran sebagian masyarakat, dan tidak semua masyarakat mengetahui teknik pemilahan sampah antara organik dan non-organik, ke depan diperlukan upaya minimalisasi dengan melalui sosialisasi dan edukasi yang lebih intensif. 


\section{REFERENSI}

Aan Komariah, Djam'an Satori (2011). Metode Penelitian Kualitatif. Bandung, Alfabeta.

Anggraini, A. D. (2015). Strategi Inovatif Pengelolaan Sampah Rumah Tangga Perkotaan (Studi Pada Bank Sampah "Sri Wilis" Perum Wilis II Kelurahan Pojok Kecamatan Mojoroto Kota Kediri). Jurnal Administrasi Publik, 3(11), 1837-1843.

Anjaswara, D. G. A., Suryawan, I. G. B., \& Suryani, L. P. (2020). Penerapan Peraturan Daerah Kota Denpasar Nomor 3 Tahun 2015 Tentang Pengelolaan Sampah. Jurnal Konstruksi Hukum, 1(1), 78-83.

Badan Pusat Statistik (BPS) diakses dari http://www.bps.go.id/, diakses pada tanggal 2 Februari 2021 pada jam 20.20 WIB.

Moleong, Lexy J. 2010, Metodologi Penelitian Kualitatif, Bandung, PT. Remaja Rosdakarya

Nugraha, I. M. S., Parsa, I. W., \& Suardita, I. K. (n.d.). Pelaksanaan Peraturan Daerah Kota Denpasar Nomor 3 Tahun 2015 Tentang Pengelolaan Sampah. Kertha Negara: Journal Ilmu Hukum.

Peraturan Daerah (PERDA) Kota Kediri No. 3 Tahun 2015 Tentang Pengelolaan sampah

Saputri, M. M. (2015). Evaluasi Dampak Kebijakan Pemerintah Daerah dalam Pengelolaan Sampah melalui Program Bank Sampah (Studi di Bank Sampah Sumber Rejeki Kelurahan Bandar Lor Kecamatan Mojoroto Kota Kediri). Jurnal Administrasi Publik, 3(11), 1804-1808.

Sugiyono. (2012). Metode Penelitian Kuantitatif Kualitatif dan R\&D. Bandung:Alfabeta.

Sulistiyorini, N. R., Darwis, R. S., \& Gutama, A. S. (2015). Partisipasi masyarakat dalam pengelolaan sampah di lingkungan Margaluyu Kelurahan Cicurug. SHARE: Social Work Journal, 5(1). 